\title{
Super-heróis, intrépidos, caretas: cultura jovem na publicidade e no documentário das marcas Shell e Esso nos anos 60 e 70
}

/////////////////// : Andréa França

\section{Cláudia Pereira}

1. Doutora em Comunicação pelo Programa de Pós-graduação em Comunicação e Cultura da Universidade Federal do Rio de Janeiro. Professora do Programa de Pós-Graduação do Departamento de Comunicação Social da Pontifícia Universidade Católica do Rio de Janeiro. Pesquisadora do Conselho Nacional de Desenvolvimento Científico e Tecnológico. E-mail: afranca.pucrio@gmail.com

2. Doutora em Antropologia Cultural pelo Programa de Pós-graduação em Sociologia e Antropologia da Universidade Federal do Rio de Janeiro. Professora do Programa de Pós-Graduação do Departamento de Comunicação Social da PUC-Rio. E-mail: claudiapereira@puc-rio.br 


\section{Resumo}

Para os estudos da comunicação, a oposição nas estratégias de propaganda entre as marcas Shell e Esso, no Brasil das décadas de 1960/70, traz à tona questões importantes para pensar o lugar da publicidade e do documentário feito para a televisão como campos - de investimento informativo, cultural, subjetivo - em disputa dentro de um mercado de consumo emergente. Trata-se de uma polaridade que irá pautar o lugar dessas mídias de massa na construção da realidade do país e na invenção de papéis sociais, como o de uma juventude que se vincularia "naturalmente" aos valores de liberdade, transgressão e mudança.

\section{Palavras-chave}

Publicidade, juventude, cinema documentário, televisão, Shell.

\section{Abstract}

For the communication studies, the opposition in the propaganda strategies between Shell and Esso brands in the 60's and 70's in Brazil brings up important issues to think about the place of advertising and documentary made for television as fields - of informative investment, cultural, subjective - in dispute within an emergent consumption market. It is a polarity that will guide the place of mass media in the construction of the reality of a country and in the invention of social roles, such as a youth, that would be "naturally" linked to liberty, transgression and change values.

Advertising, youth, documentary cinema, television, Shell. 

das marcas Shell e Esso nos anos 60 e 70 | Andréa França e Cláudia Pereira

3. Dois universitários franceses marcariam particularmente esse

"espírito" da época com suas pesquisas, como o demógrafo Alfred

Sauvy, que publicaria um livrosíntese de todas as suas enquetes sobre o tema, com o título de $L a$ montée des jeunes (1959); e Edgar Morin, que trabalharia sobretudo no recorte do lazer e da cultura jovem, tal como apresentaremos no artigo. Ver a esse respeito o livro de Antoine de Baecque, La Nouvelle Vague: portrait d'une jeunesse.
Man of the year - Twenty-five and under. Assim a capa da revista americana Time, de 1967, oficializava o que o mundo já sabia: os jovens passavam a ocupar um novo lugar na mídia e no imaginário da sociedade moderna ocidental. De meros consumidores da cultura juvenil que se consolidara com os mass media, alçavam-se à categoria de atores sociais e culturais que deixariam marcas no final dos anos 60 e no início dos 70. Dez anos antes, na França, também seriam vários os jornais e as revistas que atentariam para o "espírito" desses novos jovens, em matérias como "Jeunesse, qui es-tu?" ("Juventude, quem é você?”, La Nef), "La jeunesse et l'amour" ("A juventude e o amor", Le Figaro), "La violence des jeunes" (“A violência dos jovens", La Croix), "La nouvelle vague arrive!" ("A nova onda chega”, L'Express) e "L'influence du mode de vie américain" ("A influência do modo de vida americano", Paris-Jour), entre outros. Ainda no final dos anos 1950, igualmente, estudos mais especializados buscariam investigar comportamentos precisos, como a vida sexual dos jovens, seus sonhos, suas crenças religiosas, seus gostos culturais, seus comportamentos sociais ou delinquentes. ${ }^{3}$

Da condição de "mitologia" à de "crise", a juventude é tema de dois momentos da obra de Edgar Morin ([1962] 2009, [1975] 2006). No primeiro, esse autor debruça-se sobre uma cultura de massas em construção, delineando o que seriam os valores norteadores que a sustentavam no contexto da sociedade americana, em primeiro lugar, e no das sociedades ocidentais, num segundo momento - 
dentre os quais, a felicidade, o hedonismo, o feminino e, o que nos interessa em especial, a "juventude" - , pautando uma comunicação que homogeneíza os gostos e padroniza os estilos de vida. Quase 15 anos depois, Morin preocupou-se em retomar um "espírito do tempo", mergulhado, dessa vez, na crise moral, social e política que se instaurava, de forma profunda, num mundo mais empobrecido e desigual, que já havia passado pelas revoluções de 68, tinha sido invadido pela onda pacifista dos hippies logo depois e que, naquele momento, via-se diante da ameaça nuclear e do maniqueísmo da Guerra Fria. Uma crise que acabou por lançar uma luz sobre poetas, músicos, estudantes universitários, jovens, enfim, que francamente buscaram novos modelos, que ainda se sustentassem diante da derrocada de uma utopia humanista e libertária, traduzida em bandeiras de diversos movimentos sociais e culturais que coloriram suas roupas, suas artes e seus dias - o lugar ideal do drop out, da rebeldia das drogas e do sexo livre, das igualdades e das comunidades, do antimaterialismo e do transcendentalismo.

Antes, porém, Morin ([1975] 2006) demonstra que tudo começou com a adesão desses mesmos jovens, enquanto "classe de idade", aos movimentos feministas e antirracistas dos anos 50. Nesse processo, eles sentiram imediata identificação com os antiheróis de filmes como The wild one (1953), com Marlon Brando, e Rebel without a cause (1955), com James Dean, que os instigaram a imitar seus modos e suas modas e, sobretudo, a se organizarem em gangues pelas ruas dos Estados Unidos e Europa para, mais tarde, "perturbarem a ordem" no Brasil.

Importante destacar que o sociólogo francês vê o cinema como lugar de identificação e projeção (de desejos, sonhos, atitudes) que permitiria à juventude da época se reconhecer, se reagrupar e se afirmar como tal. Morin publica seus trabalhos em livros e na revista que acabara de criar, Arguments, e o próprio filme que realiza com Jean Rouch, Chronique d'um été (1961), prefigura surpreendentemente, na liberdade que é dada à palavra e às relações 
intersubjetivas, o movimento francês de Maio de 68. Nessa mesma época, influenciada pelos beatniks Allen Ginsberg e Jack Kerouac, entre outros artistas, a juventude descobriria nas drogas um canal para inesperadas experiências sensoriais. Como queria Morin, já se criavam, naquele momento, predisposições comportamentais e estéticas que introduziriam, primeiro, o provocativo Elvis Presley; depois, os revolucionários The Beatles e Bob Dylan; e, com eles, os hippies e suas flores. E foi assim que se estabeleciam as espacialidades jovens, marcadamente segregadas, na Greenwich Village de Nova York e em Berkeley, na Califórnia. Tais espaços expandiram-se para as universidades, de onde eclodiriam os primeiros movimentos estudantis que, em 1968, evidenciariam a ruptura ideológica e partidária com os adultos desejada pelos jovens (MORIN, [1975] 2006), refletindo nos contextos políticos já fragilizados da América Latina, da Europa e da Ásia. Estava dada a oposição simbólica que perduraria até a contemporaneidade na mídia, em suas diversas expressões, entre aqueles que têm "vinte e cinco e menos", como destaca a capa da Time de 1967, e os “outros".

Lançando um olhar atento sobre parte da produção publicitária desse período no Brasil e sobre o conceito de cinema documentário utilizado no programa Globo-Shell Especial (1971-1973), é possível encontrar não só o sutil e, ao mesmo tempo, expressivo processo de construção social daquilo que constituía o "ser jovem" nos últimos 30 anos do século XX como também entender por que a Shell decide aliar sua imagem a um programa de documentários para televisão, feito majoritariamente por cineastas. O corpus que conduz a presente análise é composto em primeiro lugar de publicações das revistas Veja e Realidade, compreendendo um período que vai de abril de 1967 a dezembro de 1970 - mais especificamente, 16 anúncios, além de matérias jornalísticas e de uma coluna de humor assinada por Millôr Fernandes na Veja —; em seguida, investigamos a proposta conceitual do programa Globo-Shell Especial, da Rede Globo, criado no início dos anos 1970, assim como um dos documentários feitos para a atração, Semana de Arte Moderna, de Geraldo Sarno. 


\section{Contracultura, juventude e conceito publicitário}

A trajetória pós-guerra da cultura juvenil está estreitamente relacionada, primeiro, com a consolidação dos meios de comunicação de massa, especialmente o cinema e a televisão, e, depois, com os movimentos contraculturais do final dos anos 60 - os quais, vale ressaltar, também se sustentam da difusão amplificada da cultura de massa, ainda que às custas de um ônus de alto risco, qual seja, o da mercantilização de seus símbolos. Considerando, portanto, a inevitabilidade da realização de tal percurso pela comunicação massiva, cabe aqui uma outra reflexão, fundamental ainda para outras às quais este trabalho pretende avançar: por quais caminhos a noção de juventude se vinculou à de contracultura, a ponto de se tornarem praticamente indissociáveis? Por quais caminhos o conceito de documentário, dentro da televisão brasileira, se vinculou à ideia de modernidade cultural, informativa, em meio às diversidades e contradições do país?

Nesse ponto, é importante recorrer à definição de contracultura. Segundo Pereira (1988), pode-se entender o termo a partir de duas perspectivas. Uma delas trata a contracultura como um fato pontual, histórico e contextualizado, relacionado a um dado momento da sociedade, nos anos 60 e 70 . Nesse sentido, os movimentos sociais e culturais da época constituem, portanto, a contracultura. Outra perspectiva, por sua vez, considera contracultura todo e qualquer movimento social ou cultural que busca romper paradigmas, derrubar modelos, transformar valores. A mesma abordagem pode ser encontrada no trabalho de Goffman e Joy (2007), no qual os autores definem contracultura como ações originalmente individuais que buscam, antes de tudo, a liberdade de expressão e o antiautoritarismo, mas também a mudança social. Sendo assim, não se podem localizar os movimentos contraculturais apenas nos anos 60 ou 70, mas em qualquer momento da história da humanidade, como quando os hackers lutam por uma internet livre (GOFFMAN; JOY, 2007).

Também Morin (2006) discute a expressão contracultura a partir da ideia de contratendência - um "feedback negativo" a uma tendência, no momento em que ela se instala como coisa 
hegemônica, dominante. Tal contratendência busca, segundo o autor, retomar uma situação que preceda à tendência como tal, configurando-se, muitas vezes, em neotribalismo ou "anarquismo sem entraves" (tipos de contracultura), por exemplo; ou, ainda, rompendo com o que é estabelecido, instituindo uma "novidade", quebrando paradigmas. Simplificando, toda contracultura é uma contratendência, mas nem toda contratendência é uma contracultura - para sê-lo, é necessário que se torne prática do cotidiano, de fato.

Delimitados os termos do que venha a ser "contracultura”, resta compreender suas relações com a noção de "juventude". Tratase, no entanto, muito mais de um encontro conjuntural do que intencional - como vimos, os jovens do pós-guerra vivenciavam um momento de construção de identidade grupal e, como tal, encontravam uma inédita visibilidade, graças à vertiginosa influência dos meios de comunicação de massa. Ao mesmo tempo, minorias oprimidas aproveitavam esse momento propício para as manifestações públicas - mediadas pelos mass media para conquistar adesões significativas às suas causas. Parece que a “natural" propensão dos jovens à transgressão e à transformação encontra, aqui, sua gênese - quando, ao contrário, configurava-se como algo socialmente construído e, por meio de diversos produtos midiáticos, rapidamente disseminado.

É na publicidade do final dos anos 60 e 70 que se percebe a presença marcante de uma dada “cultura jovem”, em anúncios de diversos produtos (Figura 1), como cigarro, tecidos ("Tebilizado Renaux é o tecido tão incansável e tão bonito como os jovens”), aparelhos de som e até mesmo café. Aliás, é também nesse momento que surgem representações do jovem a partir de símbolos contraculturais, como bem indicam os anúncios da Shell, analisados mais adiante. 


\section{SUPER-HERÓIS, INTRÉPIDOS, CARETAS:}

CULTURA JOVEM NA PUBLICIDADE E NO DOCUMENTÁRIO

DAS MARCAS SHELL E ESSO NOS ANOS 60 E 70
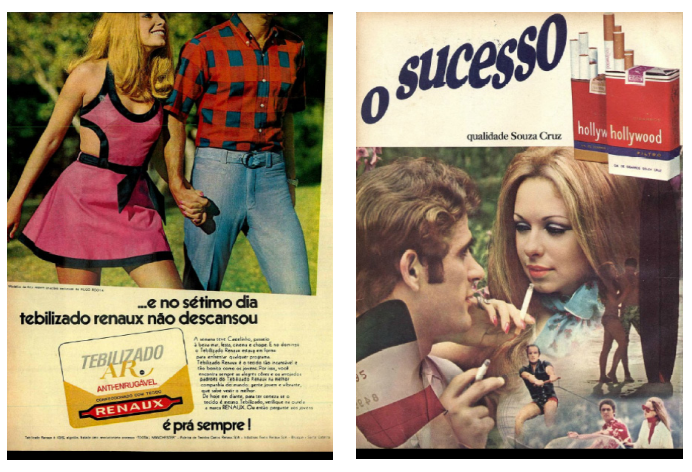
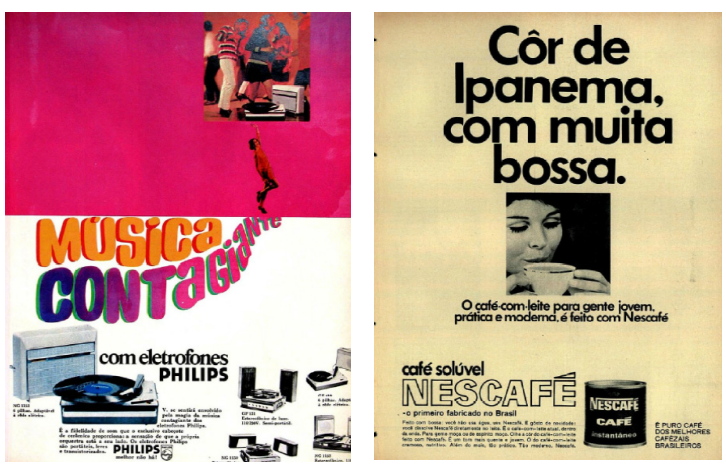

Figura 1: Símbolos da cultura jovem na publicidade dos anos $60 / 70$

(Renaux - Revista Veja, 18/09/1968,

p. 66; Hollywood - Revista Veja 14/05/1969, p. 36; Philips - Revista Veja 11/09/1968, p. 35; Nescafé Revista Veja 09/10/1968, p. 05)
Como afirmou Morin ([1962] 2009), a “juventude" é um dos valores da cultura de massa. É uma "mitologia” que sustenta um discurso que deve atingir todos, indistintamente. Esse, portanto, é o primeiro sinal de que a publicidade, como narrativa do consumo - sendo este último um sistema de significação e de classificação (ROCHA, 2010) - , transformou, desde então, a juventude num "conceito estratégico" (PEREIRA, 2010) para a elaboração de um discurso da modernidade.

\section{Tropicalismo, Shell e juventude na publicidade}

No Brasil, um dos movimentos contraculturais mais marcantes do período aqui abordado, qual seja, o final dos anos 60, é o tropicalismo (GOFFMAN; JOY, 2007). Ele se opunha a um contexto cultural dominante, pautado no discurso ufanista do início da ditadura militar, instaurado em 1964. Restaurando a proposta “antropofágica” dos anos 1920, em que produtos da cultura estrangeira (norte-americana e europeia) eram apropriados e modificados a partir de referenciais da cultura popular brasileira, de forte identidade nacional, Caetano Veloso, Gilberto Gil e Os Mutantes - deixando de citar ainda outros importantes nomes da música tropicalista - passariam a ser os seus principais representantes. E, como contracultura, o tropicalismo representava uma esperança modernista e libertária, mas sobretudo antiautoritária, diante de uma resistência cada vez mais dura da censura militar. 
A marca Shell, coerente com uma plataforma de comunicação que buscava opor-se à sua principal concorrente, a Esso, buscava associar-se a valores que representassem, de maneira positiva, uma brecha num contexto político e cultural tão hermético, tal qual se apresentava. Considerando a publicidade, como dito anteriormente, uma narrativa de um sistema de classificação, o consumo (ROCHA, 2010), é de sua natureza estabelecer e firmar tais oposições simbólicas, que tornam a marca uma espécie de totem (LÉVI-STRAUSS, 1989) - e, como tal, dotada de sentido a partir de sua relação com outras marcas-totens. Nesse sentido, observando anúncios publicitários da Shell e da Esso, é possível estabelecer pares de oposição, ou polaridades, que conduzem a certos critérios de classificação. Um deles sublinha a ambivalência como valor central (ROCHA; PEREIRA, 2009) e inerente à ideia de juventude (MORIN, 2006). O jovem não é criança nem adulto; não é responsável, mas já tem noção das consequências de seus atos; não é livre, mas precisa experimentar o mundo. A expressão dessa ambivalência pontua a polaridade simbólica das duas marcas analisadas nos anúncios de 1967 (Figura 2), em que a Shell se apresenta como "jovem super” - que gosta de quadrinhos

Figura 2: O super-herói e o "careta", jovens em oposição.

(Revista Realidade, ed.15, 1967; Revista Realidade, ed. 16, 1967; Revista Realidade, ed. 13, 1967; Revista Realidade, ed. 15, 1967) ou que pratica surfe para "fugir dessa multidão" depois de uma “semana de trabalho" - , quase um super-herói, em oposição ao “careta”, representado nas mensagens publicitárias da Esso na mesma época, na revista Realidade, por um jovem "universitário" ou de gravata, executivo, do mundo dos negócios, em busca de "um lugar cada vez melhor para trabalhar":
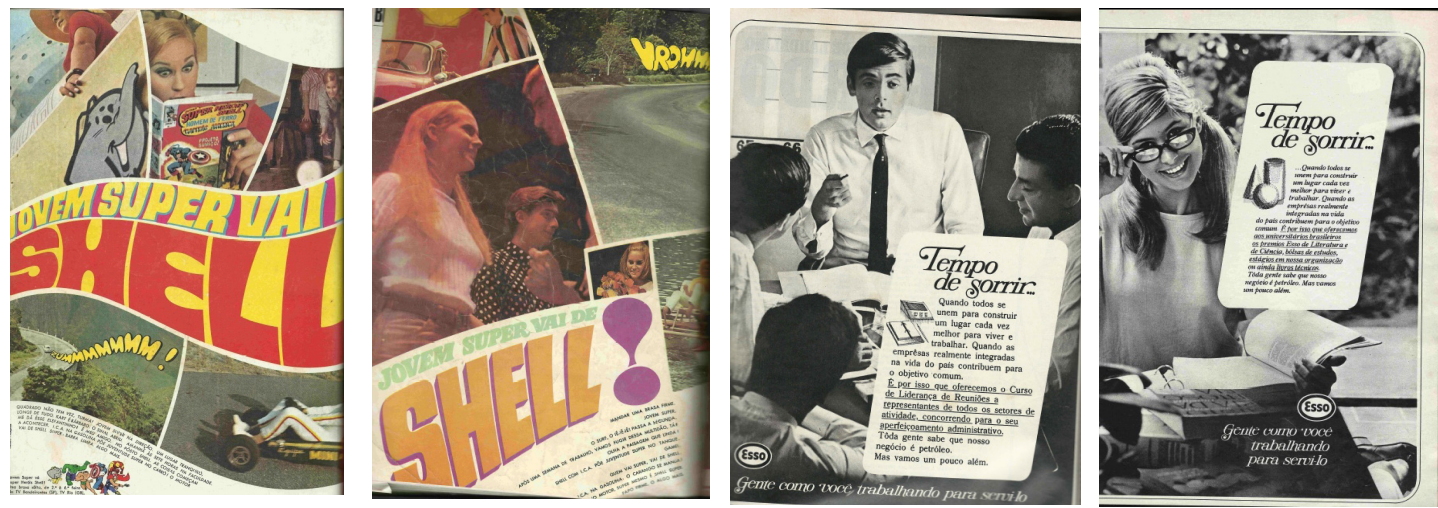
Figura 3: Aventura e Razão

Shell, Revista Veja, 25/09/1968, p. 63; Esso, Revista Veja 16/10/1968, p. 5

Enquanto a Shell incorpora estilos e posturas da pop art, do imaginário urbano, da colagem, dos quadrinhos e de valores relacionados à emoção e à aventura - "o clima pode ser quente, frio, tropical ou espacial" - , a Esso explora um estilo mais austero, ao se descrever a partir da "razão" - "Mas os cientistas da Esso já sabiam. Sabiam porque dedicaram milhares de horas às pesquisas até descobrir um aditivo que garantisse partidas instantâneas" (Figura 3):

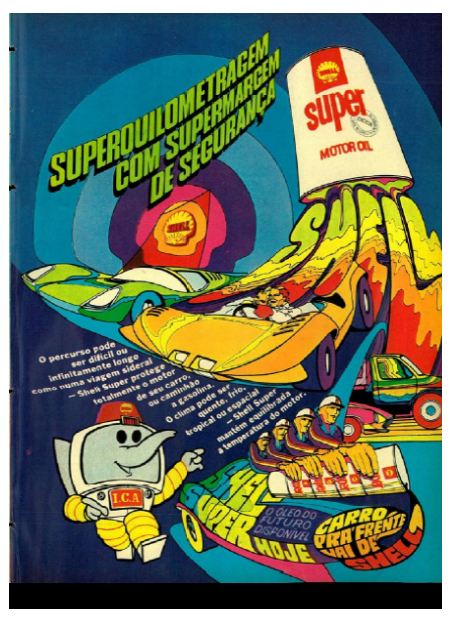

Em matéria publicada na Veja (8 jan. 69, p. 64), lê-se:

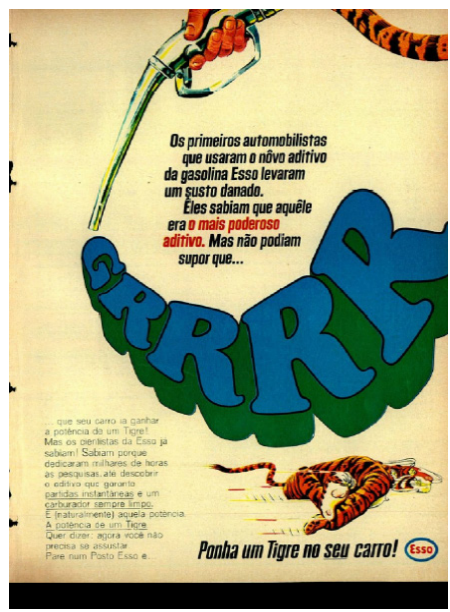

Dom Quixote combate moinhos de vento nas dunas de Cabo Frio. Vôos de helicópteros, roupas coloridas e extravagantes, cenas de perseguição e "gags" do cinema mudo - Os Mutantes estão filmando. É a nova campanha publicitária da Shell, que, dando seguimento à propaganda maciça de dois anos atrás na voz de Roberto Carlos, apela novamente para a chamada "música jovem” a fim de vender os seus produtos. Arnaldo, Rita e Sérgio receberão 100.000 cruzeiros novos por um trabalho que, segundo eles, será "novidade e além do mais muito divertido". Os três Mutantes ditarão à vontade as imagens destes pequenos filmes que pouco ou quase nada têm a ver com o petróleo e derivados. Será uma propaganda mais na base da insinuação, associando a palavra Shell a ideias e coisas agradáveis e alegres, entre as quais o "amor" surge com frequência 
quase obsessiva. "É a arte a serviço da propaganda", diz o publicitário João Carlos Magaldi, conhecido como "o homem que criou o mito Roberto Carlos".

Os Mutantes protagonizaram campanhas publicitárias da Shell (Figura 4) entre os anos de 1968 e 1969, associando à marca valores contraculturais, jovens, tropicalistas: liberdade de expressão ("Os três Mutantes ditarão à vontade as imagens destes pequenos filmes”), humanismo/erotismo (“'amor' surge com frequência quase obsessiva"), hedonismo ("e além do mais muito divertido", "associando a palavra Shell a ideias e coisas agradáveis e alegres"), juventude ("música jovem”). Arriscase, ainda, a inferir que sua imagem estrangeira no Brasil - já que a empresa é norte-americana - também seria "digerida" positivamente pela "antropofagia" do tropicalismo, misturando-

Figura 4: A agenda libertária das campanhas da Shell: diversão, cultura pop, quadrinhos

Shell, Revista Veja 09/04/1969, p. 21; Veja 07/05/1969, p. 37; Veja 21/05/1969, p. 41 se à cultura brasileira de um jeito moderno e atualizado. Em contraposição, a Esso era lembrada como a "estrangeira" e capitalista - "O cúmulo da ironia: o comunista foi atropelado pelo caminhão da Esso" (Veja, 11 dez. 68, coluna de Millôr Fernandes, "Supermercado Millôr", p. 4) - e ainda associava sua marca a um jornalismo sério e sisudo, "adulto".
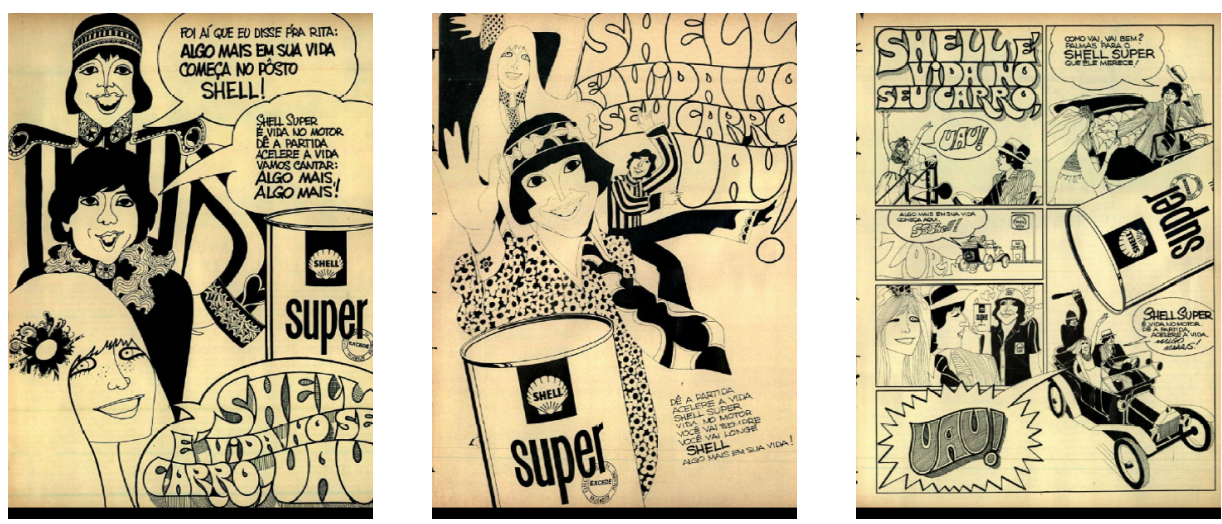

A "arte a serviço da propaganda”, como afirmou Magaldi, na citação anterior, é outro aspecto da estratégia de comunicação da Shell no sentido de se diferenciar da marca Esso - e de se contrapor a ela. Como se vê nos anúncios que servem à análise neste trabalho e, igualmente, na proposta dos documentários que irão compor o 
4. Vale destacar que, em setembro de 1960, a Shell passou a ter o cantor Wilson Simonal, que no ano

anterior era "garoto-propaganda" da Esso, em seus anúncios. Ver Veja, 24 set. 69, p. 58-59.

Figura 5: Modernidade e tecnologia, associados à juventude e futuro.

Veja 23/07/1969, p. 55; Veja 20/08/1969, p. 51 programa Globo-Shell Especial - e o Globo Repórter, em seguida —, a publicidade da marca é investida de uma dimensão artística que incorpora o modo de vida jovem, desafiador das convenções sociais, familiares, morais. A ideia é fazer da marca Shell a encarnação da juventude viva, desejável, insaciável, de um corpo dotado de uma liberdade e de uma atitude radicalmente novas.

Poucos dias depois do voo espacial que levou três astronautas norte-americanos à Lua (Figura 5), a Shell manifestou-se mais uma vez como uma marca capaz de detectar (e incorporar) rapidamente as mutações sociais, culturais e históricas então em curso. Aqui, ela já não dialogava com a cultura pop e tampouco mostrava Os Mutantes ${ }^{4}$, mas apresentava-se como aquela capaz de "ler" um momento histórico de grandes dimensões e ainda criar esquemas iconográficos que pudessem corresponder a esse acontecimento importante. O lema "Você conhece a Shell que acredita na ciência, na juventude e no ano 2001" demonstra, mais uma vez, a inteligência intuitiva da marca na sua relação com os acontecimentos, capaz de fazer da própria propaganda um campo de experimentação na sua relação com a história do mundo. Ao invés de reduzir a chegada do homem à Lua a dados estatísticos, informativos, a Shell inventava uma narrativa poética, sintonizada com o presente, que reorganizaria a própria forma da marca, sintetizando uma original incorporação dos episódios da época.
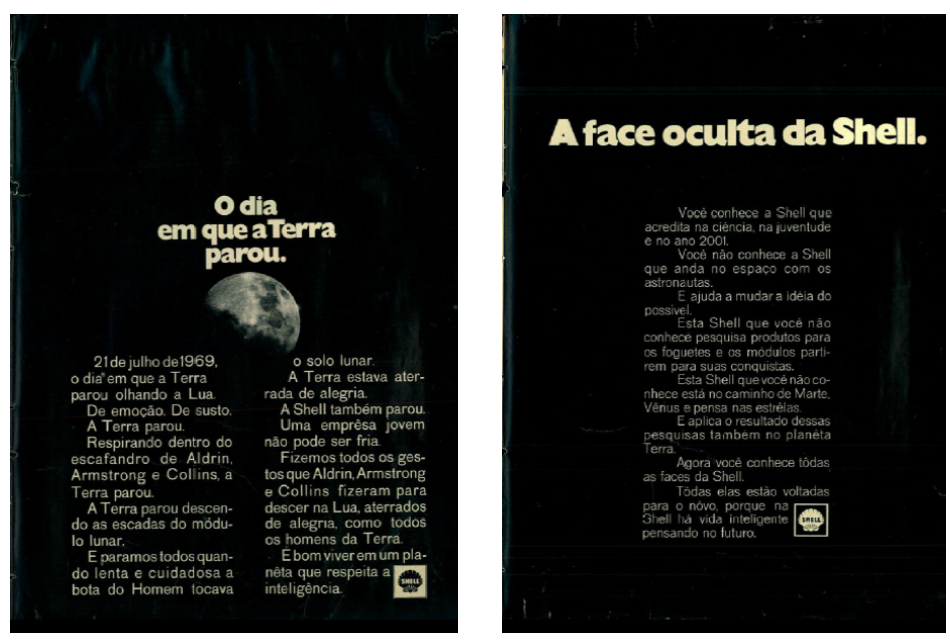
Rumo ao futuro, a Shell afirmava seu lugar no jogo publicitário, estabelecendo-se como uma marca da modernidade, da atualidade, da inovação, da poesia, capaz de detectar e digerir acontecimentos, fossem eles o advento da juventude, enquanto protagonista da sociedade de consumo, ou a chegada do homem à Lua: "A Terra estava aterrada de alegria. A Shell também parou. Uma empresa jovem não pode ser fria”.

Assim como na linguagem audiovisual do documentário, buscando "referenciar-se" através de produções que aliavam qualidade técnica ao olhar artístico de importantes nomes do cinema dos anos 1960 e 1970; e assim como nos festivais de música que patrocinou, a marca Shell buscou, também na publicidade, associar-se a valores modernos, vinculados à realidade da época e à cultura de massa do momento. Com a consolidação do regime autoritário no Brasil, a Shell iria se aliar a um programa televisivo que faria a difusão das imagens e da cultura do Brasil, um programa realizado por cineastas, feito em película, e que se diferenciaria radicalmente do telejornalismo e da reportagem tal como concebidos e praticados naquele momento.

5. Ao analisar o telejornalismo britânico da década de 1970, Dai Vaughan, em um artigo da mesma década, já denomina de "hierarquia da autoridade" a dinâmica implícita nos telejornais, em que a função do âncora, do entrevistado, do comentário, da posição da câmera seria demarcada por "códigos hierárquicos” que expõem a atitude comercial da televisão diante do telespectador. Ver: "Television documentary usage". In: New challenges for documentary (Org. Alan Rosenthal), p. 37.

\section{O projeto Shell no encontro do documentário com a televisão}

Quando a Shell decide aliar sua imagem a um programa de documentários, feito majoritariamente por cineastas, há um conceito de documentário em jogo que se coaduna com o projeto geral de modernização da Rede Globo de televisão e com a própria marca da multinacional. A série Globo-Shell Especial foi um modo de a Shell enfrentar sua concorrente, Esso, que, através dos anos, soube consolidar sua comunicação com o público ancorada no telejornal Repórter Esso, na TV Tupi, formulando através desse programa uma atitude que agregava credibilidade, seriedade e austeridade. ${ }^{5}$ Como patrocinadora do Prêmio Esso de Reportagem, premiação criada em 1955 e dada desde então ao jornalismo brasileiro, a Esso manteve sua marca associada ao imaginário de um jornalismo comprometido com a verdade e com um tipo de informação em que o repórter é sempre testemunha ocular. 
A Shell, para consolidar a sua marca nacionalmente, lança nos anos 1970 a campanha "venha assistir (sic) um dos filmes educativos Shell”, dentro do lema “o nosso melhor negócio é acreditar no Brasil”. A empresa emprestava seus documentários, gratuitamente, a escolas, sindicatos, igrejas, universidades, de modo a disponibilizar a todos "um mundo de conhecimentos úteis" (Figura 6). Vale destacar que, desde a década de 1940, a marca vinha investindo também na filmoteca Shell, com sedes no Rio de Janeiro e em São Paulo, em cujo acervo havia documentários nacionais e documentários da Shell-Inglaterra.

Figura 6: A brasilidade da multinacional forjada na Filmoteca Shell. Revista Veja 18/10/1972
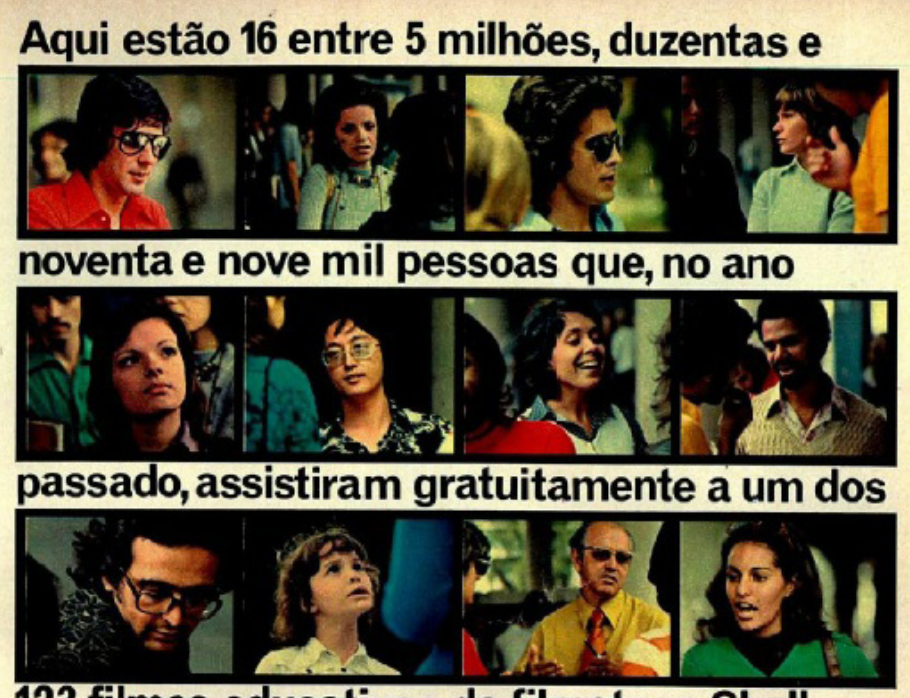

\section{3 filmes educativos da filmoteca Shell.}

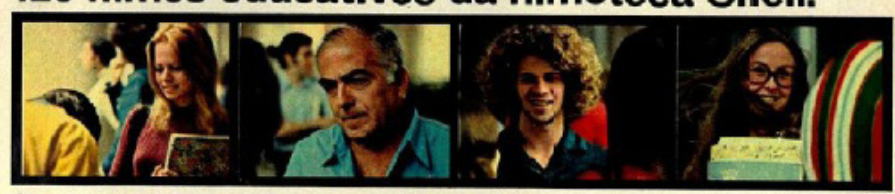

É muito provável que na sua escola, no seu clube, no

cinema da sua faculdade, da sua igreja ou de seu sindicato, você venha a assistir um dos filmes educativos Shell

sobre temas os mais variados do mundo de hoje, de suas riquezas e de seus problemas.

Emprestando estes filmes gratuitamente, a Shell

coloca a seu dispor um mundo de conhecimentos úteis apresentados sob forma agradável e gostosa de se ver.

\section{Shell}

nosso melhor negócio è acreditar no Brasil. 
O programa Globo-Shell Especial, portanto, se encaixou muito bem dentro do projeto de trazer cineastas para a televisão, de fazer uma TV moderna e informativa, com filmes que ocupariam a atenção e o interesse do telespectador das camadas médias, das universidades, da imprensa da época e que ajudariam a criar uma forma diferente de telejornalismo, menos centrado no repórter e mais aberto ao mundo e ao outro. Se a entrada do documentário na televisão britânica favoreceu, para Brian Winston (2000, p. 20), a emergência de um "jornalismo pictórico", no qual entram em cena condições de filmagem, duração, gestos, mise-en-scène dos corpos, comentário e edição, todos com possibilidade de atrair a atenção do telespectador e contribuir para escapar de um consumo cultural indiferenciado, no caso brasileiro, a entrada e o patrocínio de um programa televisivo feito por cineastas não só contribuiu para essa pictorialidade da imagem jornalística como aliou a marca da multinacional à informação, à cultura, à educação pública e, sobretudo, à arte (do cinema).

Nesse sentido, a leitura dos "Boletins de programação" da Rede Globo sobre a produção do programa Globo-Shell Especial demonstra a preocupação em abordar assuntos que estivessem sintonizados com a cultura brasileira e que fossem reconhecidos como pertencentes a ela. Documentários como Arte popular (Paulo Gil Soares, 1971), Esporte no país do futebol (Domingos Oliveira, 1971), O som do povo (Gustavo Dahl, 1972), O negro na cultura brasileira (Paulo Gil Soares, 1972), Aldeia global ou na era da comunicação (Fernando Amaral, 1972), Semana da Arte Moderna (Geraldo Sarno, 1972), Arquitetura, transformação do espaço (Walter Lima Jr., 1972), Do sertão ao beco da Lapa, vida e obra de três dos maiores escritores brasileiros: Guimarães Rosa, Manoel Bandeira e Oswald de Andrade (Maurice Capovilla, 1973) e A poluição do ar (Walter Lima Jr., 1973), para citar alguns, apontam para um desejo de olhar o país de um modo diferente, menos próximo ao tom ufanista e desbravador das reportagens de Amaral Neto, o repórter e mais ligado a uma busca por temas sociais, frequentemente urbanos, que pudessem expressar o país na sua amplitude, conflitos e contradições. O projeto do programa de mapear a cultura brasileira, mostrar o saber-fazer do homem 
do campo, informar sobre o modo de vida das pessoas nas grandes cidades deixa claro que o clamor pelas bandeiras do "real", do realismo, da realidade brasileira, tão caro à época, se aliou a um desejo (cinematográfico) de aproximação do povo, com suas falas, seus modos de ser, seus gestos.

Globo-Shell Especial, série de documentários jornalísticos abordando os temas mais importantes para o Brasil, começa a ir ao ar no dia 14 deste mês, quando será apresentado um documentário completo sobre a Transamazônica, dirigido por Hélio Polito. No dia 28 de novembro o assunto é Esporte e a direção é de Domingos Oliveira. No dia 12 de dezembro o documentário será sobre Arte Popular, com direção de Paulo Gil Soares; dia 26 de dezembro o tema será o Natal e a direção é também de Paulo Gil Soares; no dia 9 de janeiro será Habitação, com direção de Fernando Amaral. Estes são os documentários já prontos, mas a série Globo-Shell Especial tratará de outros temas do maior interesse para a comunidade, como turismo, alimentação, saúde, educação, cinema brasileiro, projeto Rondon, arquitetura e urbanismo, comunicação e música popular, todos focalizados de acordo com a mais moderna técnica de comunicação audiovisual [...] (BOLETIM, s. número, 1971). ${ }^{6}$

6. Citado em Silva, H. "Globo Shell Especial e Globo Repórter (19711983): as imagens documentárias na televisão brasileira". Dissertação defendida no Instituto de Artes da Universidade Estadual de Campinas

em 2009, sob orientação de

Fernão P. Ramos. Trata-se de uma

minuciosa pesquisa de campo na qual a autora se debruça sobre fontes

primárias diversas, como boletins de programação da emissora Globo,

críticas na imprensa da época e entrevistas com documentaristas,

técnicos e jornalistas.

7. Sob a logomarca do Globo-Shell Especial, o programa foi exibido nos lares brasileiros por mais de um ano, de novembro de 1971 até abril de 1973. A partir de então, foram exibidas algumas reprises.

Esse texto, publicado no "Boletim de programação" da Rede Globo em novembro de 1971, anuncia a estreia do Globo-Shell Especial e explicita sua meta de produzir documentários com temática brasileira e, ainda, com tratamento técnica e formalmente moderno. Foram produzidos, inspirados nesse modelo, 20 documentários sob a logomarca do patrocinador Shell. O primeiro filme do programa viria a substituir a Sessão de gala, uma faixa na programação dedicada semanalmente à exibição de filmes majoritariamente norte-americanos, aos domingos. ${ }^{7}$

Vale destacar que o programa obteve uma boa receptividade na imprensa. A Veja publicou, no dia 17 de novembro de 1971, uma matéria com o título "Perto do cinema". O início da reportagem traz uma frase de impacto: "a tendência da televisão é afastar-se cada vez mais do rádio, indo em direção ao cinema, com quem 
tem maior afinidade”. Nesse sentido, continua a reportagem, o Globo-Shell Especial foi "um passo importante", pois reuniu equipes de cineastas (Domingos Oliveira, Paulo Gil Soares, Fernando Amaral) e jornalistas (Luiz Lobo, Zuenir Ventura, Mauricio Azêdo) para a "realização de documentários sobre a realidade brasileira”. Informa ainda que o gasto dos filmes seria dividido "entre a Globo e a Shell, que trabalham em regime de co-produção". Outra matéria na Veja, intitulada "Cinema novo", em 19 de julho de 1972, destaca a substituição "dos velhos filmes" pelos documentários do Globo-Shell Especial. Para a revista, a televisão estaria "dinamizando" a programação jornalística e “aumentando para $25 \%$ ou $30 \%$ a audiência” (p. 72).

8. É com esse objetivo aliás, e com dinheiro do Estado britânico, que o documentarista John Grierson contrata a nata dos artistas de sua época, abrindo espaço, dentro do departamento Empire Marketing Board (que abrigava a produção de documentários), para uma interação produtiva entre novas propostas da arte de vanguarda, experimentais e distantes do mainstream, e a tradição documentária. Sobre isso, ver: Mas afinal... o que é mesmo documentário?, de Fernão Ramos,

\section{O documentário na TV:}

\section{entre a educação pública e a arte do cinema}

Interessa-nos agora discutir a crença de que o documentário na TV poderia ser uma variação muito particular e ligeiramente diferente das reportagens. Trata-se de uma concepção desse tipo de cinema que remonta à forte tradição da escola britânica de filmes, cujo desejo era que o documentário pudesse se transformar em arte, conquistando, como os clássicos do cinema mudo, a intelectualidade, os artistas e um público amplo. ${ }^{8}$ A concepção do documentário como expressão individual, livre era o que permitiria, ainda segundo essa tradição, se distanciar da reportagem, dos travelogues ou dos filmes científicos e garantir recursos financeiros para as obras. Ao escrever sobre travelogues e planos da natureza, o escocês John Grierson, documentarista e mentor/teórico dessa tradição, diz que "eles descrevem, e mesmo expõem, mas, em qualquer sentido estético, só raramente revelam”. Os documentários deveriam ser muito mais, pois eles "podem ultrapassar as simples descrições do material natural” e produzir novos arranjos e associações a partir desse material (GRIERSON apud WINSTON, 2000, p. 20). Desse modo, o "tratamento criativo da atualidade", expressão de Grierson que marca a diferença do documentário em relação às outras práticas cinematográficas, promoveria intuições, insights, e não simplesmente reflexões mecânicas sobre o mundo. 
Assim, o documentário incluiu o uso de imagens do mundo real para propostas de expressão pessoal; estimulou o "tratamento criativo" das atualidades para a obtenção do status artístico já conquistado pelo cinema clássico ficcional; permitiu o uso de imagens poéticas, ensaísticas e polêmicas; e, no que tange à produção, claramente permitiu a reconstrução de eventos testemunhados previamente, o comentário, o som dublado não naturalista, a edição para produzir um ponto de vista específico e todo tipo de intervenção e manipulação. Se o documentário não era jornalismo, então poderia clamar por todas as licenças artísticas da ficção, com a única obrigação de que suas imagens não fossem atuações de atores e que suas histórias não fossem produto de uma imaginação livre. É claro que há inconsistências lógicas na definição e nas posições de Grierson, como marca Brian Winston (2000, p. 21); afinal, o que sobraria da "atualidade" depois que ela tivesse sido "criativamente tratada"? Mas, como enfatiza, tais inconsistências descortinaram um horizonte de expressões criativas que muito iluminaram a vida do século XX.

Há outro aspecto que remonta à tradição e à concepção da escola britânica do documentário dentro do projeto dos programas Globo-Shell Especial e Globo Repórter, que viria a substituir o primeiro. Trata-se do papel de educação popular creditado à imagem documental e do seu potencial de construção de uma consciência democrática. Se a escola britânica constituiu o primeiro momento no qual o documentário pensa sobre si mesmo, enquanto forma narrativa particular, ela também respondeu às expectativas do investimento estatal, através de seus procedimentos de linguagem e de suas escolhas estéticas. Assim é que seus filmes continham um viés claramente educativo, uma "visão missionária do documentário", na medida em que se destinavam- a educar as massas para a democracia liberal e ainda fazer propaganda dos produtos e da indústria britânica (RAMOS, 2008, p. 56).

É esse pensamento a respeito do cinema documentário que, entre outras questões históricas, políticas, econômicas e culturais, favorece a entrada dos cineastas na Rede Globo nos anos 1970 (FRANÇA, 2012); artistas cuja trajetória política de "esquerda" 
9. Lauro César Muniz, autor de uma das novelas das oito horas da Rede

Globo nos anos 1970, estava proibido de usar a palavra "multinacional" para designar a nova indústria de laticínios que iria se implantar na cidade fictícia de Pilar. Em Maria R. Kehl, "Um só povo, uma só cabeça, uma só nação”, 2005, p. 423.

10. Winston (2000, p. 45) lembra que as emissoras norte-americanas são herdeiras, assim como as britânicas, de uma tradição de produção de documentário de "educação pública" fundada no Estado, destacando porém que nos EUA o pensamento sobre "serviço público” sempre foi dominado pelas ideias de mercado. agregava justamente o capital simbólico necessário para adensar a dimensão artística desses programas na televisão (SACRAMENTO, 2011). Se considerarmos esse raciocínio da distinção e da conferência de legitimidade para tratar do Brasil, tudo indica que o convite feito a cineastas para trabalhar na emissora tinha como foco a divulgação de assuntos que colaborassem com o ideário cívico das boas ideias e/ou das boas causas - incluam-se aí assuntos que não estimulassem movimentos contrários aos norte-americanos ou que explicitassem a importância do capital multinacional. ${ }^{9}$

O que se vê, em ambas as séries (no Globo-Shell e, posteriormente, no Globo Repórter), são temas que permitiram aos telespectadores ver, em rede nacional, o que faziam os sertanejos quando estavam com fome, o que pensavam os negros baianos de suas relações com o continente africano, como vivam as empregadas domésticas nos grandes centros urbanos, como se deu a emboscada que levou à morte de Lampião e Maria Bonita no interior de Sergipe, o que tinham a dizer mulheres que nos anos 30, ainda jovens, decidiram abandonar suas famílias e partir para a vida dura, porém libertária, dentro do Cangaço. Se o documentário na TV foi usado para arquivar consenso social, como afirma Jane Chapman (2009), é porque ele foi abraçado com os olhos voltados para o futuro, resultado de certas relações de forças que detinham o poder e que permitiriam à memória coletiva recuperá-lo mais à frente.

Nesse sentido, o casamento do documentário com a televisão brasileira seguiu a tradição que concebia a produção documentária, dentro da TV, como um empreendimento de educação pública, capaz de enunciar asserções sobre o mundo através de procedimentos expressivos e $\operatorname{artísticos}^{10}$. A marca Shell e a Rede Globo buscaram atualizar esse ideário de ética educativa do filme e conjugaram a ele os valores da época de unificação da linguagem, da vida urbana e moderna, do consumo e dos padrões pequeno-burgueses. Assim, os hábitos e as tradições do brasileiro foram:

aceleradamente substituídas pelas crenças mais seculares e mais coerentes com o ritmo do país: a fé na felicidade via consumo, no poder das cadernetas de poupança, na viabilidade da casa própria e carro do ano 
11. Vale destacar, dentro dessa discussão, que, se a programação da TV Cultura do Estado de São Paulo conquistou tamanha legitimidade e credibilidade por parte do público

em geral, é porque dedicou, sobretudo a partir da década de 1970,

grande espaço ao documentário. Além de extensa produção própria,

há importantes iniciativas dessa emissora estatal no campo da difusão e do fomento da produção audiovisual brasileira, com diversas

parcerias e apoios institucionais.

Do início da década de 1970 até

o processo de redemocratização

dos anos 1980, a TV Cultura manteve uma produção contínua de documentários, constituindo um dos principais, senão o principal, espaço de exibição desse cinema. Para uma

discussão sobre o documentário dentro da programação da emissora paulista, ver: A TV Cultura de São Paulo e a produção de documentários (1969-2004), tese de doutorado em ciências da comunicação de Flávio Brito, defendida na Universidade de

São Paulo no ano de 2009. comprado com crédito facilitado; ufanista do seu terno novo e da bela fachada da agência bancária próxima à sua residência - assim como do supermercado inaugurado há pouco - para sua maior comodidade. Esse homem convicto do progresso do seu país, que faz dele o cidadão participante de um novo sonho, endividado e angustiado, assoberbado de trabalho e de desejos de ascensão (KEHL, 2005, p. 409).

A incorporação do documentário à telinha marca ainda, para além dos ideais de prosperidade em jogo como assinala a autora (acima), o entendimento da televisão, mais especificamente da Rede Globo, como uma membrana que deveria envolver todos os brasileiros, colocar uns em contato com outros, criar identidade e ter como missão cívica cuidar da sorte comum de todos, das relações no interior dos diferentes grupos e entre eles. É sob esse prisma político e igualmente estético de pesquisa e de criação de modelos sociais, de vida em conjunto - que a entrada do documentário e de cineastas na TV brasileira se justifica. ${ }^{11}$

\section{Se oriente, rapaz, pela constelação do Cruzeiro do Sul}

É possível apontar conexões entre as experiências da Caravana Farkas e o projeto Globo-Shell Especial. Basta lembrar que os cineastas Paulo Gil Soares, Geraldo Sarno, Sérgio Muniz e Maurice Capovilla, que integraram a equipe de cineastas do programa da Rede Globo, partiram para o Nordeste, no final dos anos 1960, organizados em torno do fotógrafo e produtor Thomaz Farkas, com o intuito de realizar um projeto pioneiro na área da documentação de manifestações da cultura popular brasileira, com liberdade para experimentar tanto os procedimentos tradicionais da reportagem quanto os da ficção, improvisos e registros diversos. Essa proposta, explorada no campo do cinema, permaneceria com a entrada desses cineastas na televisão, ampliando seu centro de interesse para o Brasil urbano e para a indústria cultural emergente.

Entre os filmes que compõem o projeto Globo-Shell Especial, destacamos Semana de Arte Moderna (direção Geraldo Sarno), porque, ao registrar as comemorações do cinquentenário da 
Semana de Arte Moderna, o documentário, exibido no mês de julho de 1972, retoma temas caros ao modernismo artístico, à modernidade, à cultura de massa em meio a um contexto de repressão política e dependência econômica. Com narração de Cid Moreira, de um texto original de Zuenir Ventura, o filme passeia entre procedimentos e imagens de origens diversas, buscando o engate entre a antropofagia de Oswald de Andrade, capaz de transmutar a dominação em assimilação, e sua utopia no presente, com as antenas de televisão, a ditadura militar, as performances artísticas, o discurso da liberação sexual, o tropicalismo.

Ainda que a narração de Cid Moreira oriente e dirija o olhar do telespectador, é surpreendente assistir a uma montagem de material de arquivo de origens tão diversificadas: trechos dos filmes São Paulo: sinfonia da metrópole (1929), Ipiranga (1922)12, inacabado,

12. Sobre esse filme inconcluso, ver "Um apóstolo do modernismo na Exposição Internacional do Centenário: Armando Pamplona e a Independencia Film", no qual o autor, Eduardo Morettin, busca estabelecer as possíveis relações entre esse projeto fílmico e a participação da produtora de Armando Pamplona

na Exposição Internacional do

Centenário da independência

brasileira, de 1922. Trabalho apresentado no XXI Encontro da Associação Nacional dos Programas de Pós-Graduação em Comunicação, em Juiz de Fora, em 2012.

Disponível em: http://www.compos. org.br/pagina. php?menu= $8 \&$ mmenu $=0 \&$ fcodigo $=1890$. e Macunaíma (1969) e do documentário curta-metragem Chico, retrato em branco e preto (1968), no qual estão trechos da peça O rei da vela (1967); há também imagens do acervo do grupo Oficina (o depoimento de José Celso e a montagem da peça Gracias, señor, de 1972), da apresentação do circo Piolin no Museu de Arte Moderna de São Paulo (1972), da exposição comemorativa do cinquentenário e de depoimentos históricos de intelectuais e artistas, como Antonio Candido, Gilberto Gil, Waly Salomão, Di Cavalcanti, Joaquim Pedro de Andrade, Tarsila do Amaral, José Celso Martinez e Caetano Veloso, entre outros, além de fragmentos da trilha sonora do filme Terra em transe (1967).

Das enquetes feitas nas ruas de São Paulo - "Você ouviu falar da Semana de Arte Moderna?"; "Não, não ouvi falar não, mas deve ser coisa boa, porque tudo que é moderno é bom..."; "O que o senhor sabe da Semana de Arte Moderna?"; "Acho muito interessante essa modalidade de arte porque é um assunto que interessa ao povo de São Paulo e do Brasil [...]. Faço votos que esse programa corra bem porque é de interesse nacional" - à multidão de jovens em um show de Gilberto Gil, logo após o seu retorno do exílio, o filme faz ressoarem temas, motivos, referências, numa montagem polifônica que destaca a atualidade e o diálogo da antropofagia com o tropicalismo, dos sonhos modernistas com 
a complexa realidade de um país marcado pelo rastro de uma modernização perversa, pelo crescimento urbano desordenado e "espetacularizado" e pela brutalização da política (que caracterizaria a vida brasileira nesses anos).

Destacamos, para os limites desse artigo, o final do filme, quando a câmera passeia pelos rostos de jovens aglomerados à espera do show de Gil. Uma multidão bonita, urbana, composta majoritariamente de estudantes da classe média. Seria uma celebração do documentário à arte, à música, à poesia, que resistem apesar de tudo? O gesto de passear com a câmera por esses rostos (nos quais reconhecemos personagens da cena cultural como Waly Salomão, Sergio Santeiro...) possibilita, hoje, recordar o Maio francês, as minissaias, as manifestações estudantis contra a ditadura no Brasil e na Argentina, as lutas pelos direitos civis nos EUA, a resistência armada, a repressão, a tortura... Tudo está ali, potencialmente, contido nesse gesto. Assim como a montagem, que - ao mostrar, sucessivamente, cenas urbanas, helicópteros e multidões caóticas dos arquivos cinematográficos, fotografias de personagens literários, marcos arquitetônicos, automóveis, bondes, performances teatrais, artistas exilados pelo regime repressivo coloca a realidade da modernização autoritária sob a perspectiva de um movimento narrativo em fuga, adverso.

Destacamos também a crença, implicada no próprio gesto da montagem/colagem, de que o trabalho por entre as brechas da reportagem poderia suscitar um pensamento crítico a respeito do país e da cultura do espetáculo, a crença de que o cinema documental seria o lugar do desvio, mesmo que imerso na efemeridade de uma mídia de massa (Rancière, 2011). Assim, ainda que os documentos (fotográficos, audiovisuais) utilizados no documentário funcionem como elementos que expressam a verdade da época e ilustram a escrita da história da cultura brasileira, a montagem de um material diverso e heterogêneo induz um efeito de conhecimento que não se reduz simplesmente à cronologia dos fatos. Interessa ao filme o modo de manejar esse material lacunar, disperso, contraditório, buscando os feixes de relações entre os acontecimentos 
dos anos de 1920 e 1970, os diálogos entre a performance visceral do grupo Oficina para Gracias, señor e as práticas artísticas modernistas, o gesto comum de instaurar um campo experimental e de intervenção crítica pela desmontagem no uso dos materiais expressivos (DIDI-HUBERMAN, 2009).

Como se o documentário, conscientemente ou não, demonstrasse, pela montagem e pela colagem de imagens em movimento da década de 20, o conhecimento de que:

\footnotetext{
o cinema nasceu no momento das grandes suspeitas sobre as histórias, no tempo em que se pensava que uma arte nova estava começando a nascer e que ela não contava mais histórias, não descrevia mais o espetáculo das coisas, não apresentava mais os estados de alma dos personagens, mas inscrevia diretamente o produto do pensamento no movimento das formas (RANCIÈRE, 2011, p. 16).
}

Tal análise nos interessa para tirar os documentários do programa Globo-Shell Especial de uma leitura excessivamente delimitada ao contexto histórico e político do momento, inserindo as questões formais e estéticas numa teoria mais ampla das modernidades periféricas, cumulativas, simultâneas; dentro dessa perspectiva, o documentário de Geraldo Sarno, ao tecer relações de proximidade entre os anos 20 e 70 no Brasil, aponta para uma modernidade falhada, incipiente, cindida.

Na revista Veja de 23 de fevereiro de 1972, uma matéria com o título de "A Semana aos 50 anos" resume bastante bem o significado do cinquentenário em meio a um contexto político de repressão: "Mas o azar sublime da Semana [de Arte Moderna] foi comemorar em 1972 seu sonho das palavras em liberdade" (p. 72). $\mathrm{E}$ as palavras declamadas pelo jovem Waly Salomão, no final do filme feito para o Globo-Shell Especial, retomam ludicamente essa ideia: "Continuamos na marcha das utopias!", diz o poeta, em meio à multidão que espera o show de Gil. Ele declama para a câmera no embalo da trilha sonora do músico baiano, Oriente. 
Tal "marcha", com o apoio da Shell, pôde apostar na criatividade, na expressão individual e livre do artista, do mesmo modo que, na década de 1960, a multinacional investiria numa agenda libertária, em consonância com o ideário jovem, da música e da cultura pop. É claro que apoiar a realização e a difusão do documentário na TV significou não só a consolidação estratégica da marca no imaginário dos brasileiros mas também a crença na missão cívica de um projeto que, diferentemente da reportagem televisiva (Esso), poderia, ao menos idealmente, inovar, renovar, inventar um modelo de televisão e de sociedade no Brasil. 


\section{Referências}

BAECQUE, A. de. La Nouvelle Vague: portrait d'une jeunesse. Paris: Flammarion, 1998.

CHAPMAN, J. Issues in contemporary documentary. Cambridge: Polity Press, 2009.

DIDI-HUBERMAN, G. Quand les images prennent position: l'oiel de l'histoire 1. Paris: Éditions Minuit, 2009.

FRANÇA, A. "O pensamento do documentário na televisão brasileira: a década de 1970”. Eco-Pós: revista do Programa de PósGradução da Escola de Comunicação da UFRJ, v. 14, n. 2, 2012.

GOFFMAN, K.; JOY, D. Contracultura através dos tempos: do mito de Prometeu à cultura digital. Rio de Janeiro: Ediouro, 2007.

KEHL, Maria R. "Um só povo, uma só cabeça, uma só nação". In: NOVAES, A. (Org.). Anos 70: ainda sob a tempestade. Rio de Janeiro: Aeroplano, 2005.

LÉVI-STRAUSS, C. O pensamento selvagem. Campinas: Papirus, 1989.

MORIN, E. Cultura de massas do século XX: o espírito do tempo I. Neurose. Rio de Janeiro: Forense Universitária, 2009.

Cultura de massas do século XX: o espírito do tempo II. Necrose. Rio de Janeiro: Forense Universitária, 2006.

PEREIRA, C. A. M. O que é contracultura. São Paulo: Brasiliense, 1988.

PEREIRA, C. "Juventude como conceito estratégico para a publicidade”. Revista Comunicação, Mídia e Consumo, São Paulo, v. 7, n. 18 p. 37-54, mar. 2010.

RAMOS, F. Mas afinal... o que é mesmo documentário? São Paulo: Senac, 2008.

RANCIÈRE, J. Les écarts du cinéma. Paris: La Fabrique Éditions, 2011 . 
ROCHA, E. Magia e capitalismo. São Paulo: Brasiliense, 2010.

ROCHA, E.; PEREIRA, C. Juventude e consumo: um estudo sobre comunicação na cultura contemporânea. Rio de Janeiro: Mauad, 2009 .

SACRAMENTO, I. Depois da revolução, a televisão: cineastas de esquerda no jornalismo televisivo dos anos 1970. Pedro \& João Editores: São Carlos, 2011.

SILVA, H. "Globo Shell Especial e Globo Repórter (1971-1983): as imagens documentárias na televisão brasileira". Dissertação (mestrado) - Universidade Estadual de Campinas, 2009.

WINSTON, B. Lies, damn lies and documentaries. London: British Film Institute, 2000. 